\title{
THE RELATIONSHIP BETWEEN ECOTOURISM CLUSTERS AND INNOVATION MILIEU IN THE REGION OF SOUTH-EASTERN EUROPE
}

\author{
Economist Ágnes Fodor, VÁTI Non-profit Company, \\ e-mail: fodoragil@t-online.hu \\ Economist László Sitanyi, South-Transdanubian Regional Development Agency, e-mail: \\ sitanyi@somogy.hu
}

\begin{abstract}
Ecotourism destinations can be characterised with typically standalone tourism suppliers. Although competition can be useful, but often cooperation among such small operators yields significantly better overall results. Harmonising nature conservation and tourism is also an important condition of sustainability.

Availability of financial assets is also important; but contrary to conventional wisdom the main questions is not the capital available for innovation or the government's grants. According to research, success does not depend on the support of the government, but primarily on the environment, or the so-called milieu of innovation (CAMAGNI, P.R. 1992).

Based on our research we can develop ecotourism clusters in peripheral EU countries that are economically and socially successful and at the same time provide a liveable environment.
\end{abstract}

Keywords: Innovative environment (milieu), Ecotourism, Ecotourism Clusters, Networks, Spatial development

JEL Codes: L83, O30

This article has been sponsored by research project of OTKA - T49291

\section{Introduction}

This paper gives an overview of the economic paradigms, innovations, co-operating systems and clusters that make the regions successful in our post-industrial society. I would like to select the experiences gained in economic development of the post-industrial economics as an example based on mainly small and medium side enterprises (SMEs), which are assumed as elements that can be implemented in the regions of Balkan.

The modern state does not only subsidize the competitiveness of its own national economy, as its competitiveness firstly depends on the underlying innovative environment, the so-called 'innovation milieu' (Camagni, P.R. 1992) and the national innovation system, which binds the system together.

The directions of economic development and the influencing factors are featured by the duality of local-global processes that has become a professional stereotype. The relating literature that is as wide as a whole library reports various, often contradictory statements, however there is a considerable agreement in that the localisation of economic activities has been up-valued by information, capital and labour flow and the globalisation of market.

Thus the defined direction of economic and market development strengthened the role of regional economic development, the significance of local economic development policy and planning and also its spatial economy-managing functions (Hrubi 2004).

All these affected even the mainstream of economics, despite having neglected any regional approach for more than hundred years (with the exception of short periods). The reviewing publications of economics (e.g. Samuelson and Nordhaus 1988) represent the theory that economic processes can be pointwise modelled, besides of transportation costs these do not have spatial 
relations. Until the 1990's, peripheral disciplines (such as regional economics, geographic economy, economy of settlements, domicile theories) dealt only with the question of space (Varga 2003).

A highly different approach was brought about by the "new world economics" starting from North America at the beginning of the 1990's, which considers that the revealing of the causes of developing the spatial structure of economic activities as the central objective of economics. According to Paul Krugman (1991, 1993), the real planning units of economic analysis (and thus that of strategic planning of economic development and of the execution of regional strategies) are not those of the countries but those of the regions forming the countries.

The nature reserve areas and the international waters are sensitive areas, whose tourism utilisation is pressed by not only inland factors, but environmental effects from foreign states as well. In order to sustain these kinds of tourism attractions there is a special need for both inland and international co-operation. Tourism can be a mediator, as the development of tourism is a highlighted sector among the aims of both Hungary and Romania, and for reaching this aim clean and attractive environment is indispensable.

The current study seeks for the answer on the questions: why does not the institutional system $^{1}$ of regional development built with the support of the EU work effectively in these countries; and what changes are necessary in the central regulation, the legal framework and what sorts of warrantees are needed in order to sustain and effectively operate the investments supported by national and EU funds?

\section{Regional level, innovation environment}

The professional literature has been showing a strengthening harmony in that the regional level has a determining role in the development of innovation milieu. Numerous books have been published both in international literature and in Hungarian that intend to define the sources of innovativeness (Rechnitzer 1998, Dőry 2005). Although these are built on different databases and apply various approaches and use even different analytical units, these agree that innovation is the key factor of:

- Improving international competitiveness;

- Economic growth;

- And improving living standards (Ács and Varga 2002).

The new regional development strategy built on innovation has always been seen in interregional facilities, the use of potentials, and the renewing and developing of own resources in several industrialised countries. Developments built bottom-up on regional potentials as endogenous resources are expected to:

- Promote initiatives of development, renewal;

- Create programs that are different from the earlier centralised ones and are formed suitably on and re-evaluating of the natural, environmental as well as regional economic conditions, which are integrated in the cultural-social traditions of certain regions;

- Reveal new, non-used resources in the strategic and operative decisions and actions with the participation of the local civil society and people.

The regional conditions and potentials have got to the front of new regional policies, which can be activated in suitable circumstances as endogenous resources for developments.

There are several approaches to this issue, but all agree that local and regional communities who have realised the value of their specific, natural local endowments, traditions in production and the unique skills of the available labour force, thereby activating the regional political aims and cultural conditions gain a comparative advantage on other regions.

\footnotetext{
1 According to Faragó László (2004) the administration of spatial development is exaggerated and financed well in Hungary.
} 


\section{Social capital is necessary to build the network of local co-operations}

According to Fukuyama, F. (1995) economic life is wedded to culture: to such 'irrational' values that are bounded to morals, ideas of community, family, religion and where therefore the rules of the neoliberal economics operating with mainly interests and rational decisions limitedly prevail. The main objective of modern societies is to sustain or create high level of social trust and social capital, because the lack of these inhibits economic development as much as the scarcity of physical capital.

According to Robert D. Putnam (1993): "social capital comes from the features of social organisations, such as trust, norms and networks, which can improve the effectiveness of society by promoting harmonised activities".

\section{Global processes, local development}

In regional development, the role of horizontal relations, local (not only economic) culture, traditions, and innovation milieu increases; while the regions (subregions, or especially in Hungary certain settlements) are fighting for acquiring economic activities, especially high-tech industry (Stöhr 1988). Local communities face stronger competition.

Only those that are able to present uniqueness can achieve results and maintain it within rapidly changing environment or even improve it in long term; and to make it attractive for investors in the global competition.

Those who start fighting for resources need to understand that 'Europe of the Regions' is not only a theory of cooperation, but also has a strong economic competition, where the borders neither separate, nor defend any more.

\section{Innovation and government support}

Capital both in cash and assets is also important; but contrary to the general approach the main questions are not the own capital available for innovation or the government's grants. According to researches, success does not depend on the support of the government, but primarily the environment, milieu of the innovation. (Camagni 1992) The post-modern innovation is a complex system (Döry 2005), where the research and market potentials interact in a multi-feedback model in a much more complex way than the earlier linear and chain models - almost parallel due to the information development. (Sitányi 2005)

\section{Entrepreneur as the 'carrier' of innovation}

In developed economies, potential for innovation is a determining factor of the business competitiveness. Research and Development is important, but contrary to the general approach, the main question is not the role of the government support, but the way how the companies recognise their opportunities and answer the challenges. The success of a country or region is primarily dependant on how the local actors can build efficient relations between the phases of the innovative processes and how effective their regional networking ability is; because these regional networks provide the basis of the interactions that integrate the geographically separated economies in the global network of trade and industry (Fritsch et al. 1998). Thus, primarily the small and medium size enterprises (SMEs) benefit most from the regional and indirectly global networks.

In Hungary the New Hungary Development Plan there are special measures for improving the small and medium size enterprises and also for the spin off different types of clusters. 


\section{Clusterisation in Hungary}

The clusterisation of small and medium sized enterprises is basically beneficial from the aspect of their future market opportunities. In general, the Hungarian enterprises have inadequate amount of own capital for the European market competition and technological and product developments. Without any innovation it is impossible to maintain an existence in the future. The clusters integrate the separately operating small enterprises, while retaining their image and ensure additional income for the members of the integration. The clusters help to develop business networks of small and medium enterprises and to build both horizontal and vertical connections among different enterprises, research institutes and organisations.

In Hungary, the first clusters were formulated in the Western-Transdanubian Region, primarily in relation with industrial production, such as the automotive industrial cluster, which started with the concentration and co-operation of different players working in certain phases of the production.

Between 2004-2006, the European Union Funds supported the development of several clusters in Hungary. As the result of this period, 9 regionally organised tourism clusters were formulated within the framework of one of the prominent sectors of tourism, health tourism. These clusters were established in the Western and South Transdanubian regions, on South Great Plain, in North Hungary and on North Great Plain (Pannon thermal cluster, North Great Plain Thermal cluster, South Transdanubian thermal cluster, south Great Plain bath cluster, North Hungarian health-tourism cluster, Jász-Nagykun-Szolnok county thermal cluster). The aim of the development of the clusters was to foster the development of tourism by involving the actors of (thermal and medical) tourism in the area/ region.

The Hungarian tourism clusters, are basically spatial co-operations with marketing approach regarding their main activities, thus these belong to the local and horizontal clusters. In case of ecotourism clusters ${ }^{2}$ the conservation and professional interpretation of nature reserve areas and natural values and the conscious direction and management of tourism necessitate not only locally and horizontally co-operating partners.

\section{Ecotourism cluster}

Small ecotourism and related supply chain businesses in gateway communities can be linked to protected areas by organizing them into competitive clusters focused on their comparative advantages and uniqueness.

The core of the "cluster" is the comparative advantage represented by a protected area's natural attractions and biodiversity. The competitive cluster is used to examine and support a set of strategic relationships between donors, the private sector and government in a specific program of support to ecotourism development linked to improved management of a country's protected areas.(Hawkins, 2001)

In order to be competitive, all destination players must work together by identifying the elements that make up the destination, beginning with the reasons tourists will travel to the area, the services available to them and the activities that support the tourist services.

\footnotetext{
2 According to a research using Delphi method by Ágnes Fodor in 2006, the Ecotourism cluster is: "System based on the uniform utilisation and nature conservation principles and the facilities of the land, in which the nature conservation and tourism enterprises and organisations take part simultaneously competing and cooperating with each other, for reaching more economic and social benefits. They accept as a common aim the development and the preservation of the harmony between the nature conservation and the presentation of the natural values. In this organisation tourism does not exceed the environmental capacity of the destination together with the other local economic activities."
} 
The main objective of the ecotourism cluster is that the organisations participating in it realise more economic profit than they could as independent organisations in the market, while more tourists are coming more steadily all year around while the natural values are conserved and sustained jointly.

Supply of experiences

Besides the ecologic values, the cluster integrates the specialties of the (folk)art - cultural aspects, traditions, the specialties of the local economic, civil participants (e.g. historical, traditional, fishing, sport, gastronomy, hand crafts, local agricultural entrepreneurs). Nevertheless, it presents the role of the bio-initiatives as well as the ecologic values (e.g. the use of natural materials, alternative energy, the handling of sewage and communal waste with bio methods).

The potential participants of the cluster are demonstrated in the following figure:

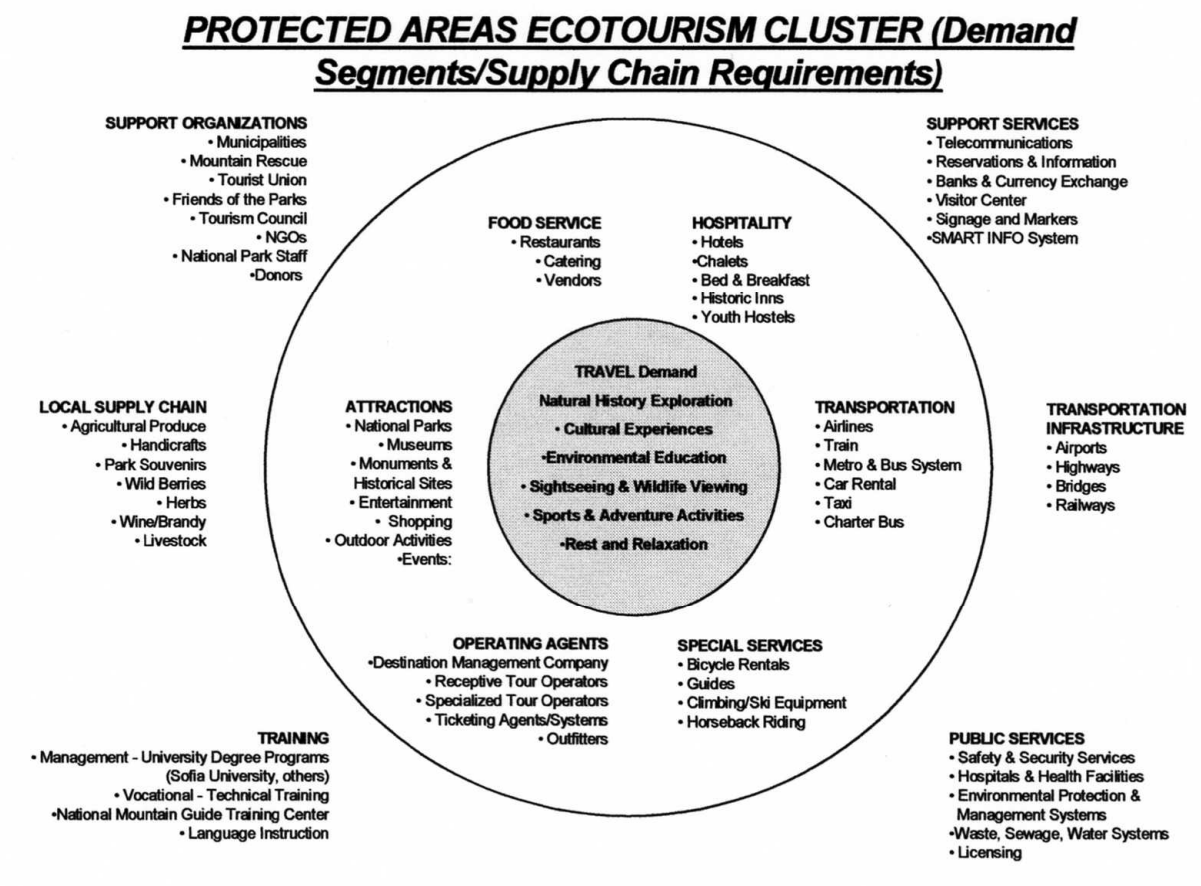

Fig. no. 1. The potential participants of the cluster

Source: Donald E. Hawkins, 2001. Protected Areas Ecotourism Competitive Cluster Approach to Biodiversity Conservation and Economic Growth in Bulgaria

The characteristics of the ecotourism cluster:

1. It can be connected to a relatively well understood territorial unit (e.g. region of DanubeDrava, Tisza). (not necessarily conforming to current administrative or statistical borders)

2. There is a close co-operations, common values, goals and ongoing dialogues between the participants

3. The participants are able to explain synergic effects on each other in their participation of mutual confidence organisations (in the fields of natural conservation, environmental conservation, tourism, relating services, infrastructures).They are able to define cluster specific services and development ideas for reaching the common goals.

4. It meets the requirements of the long-term sustainability of the tourism destinations.

5. Participation of committed cluster-members, assuring the financial background.

6. Establishment of the self-management and organisation. 
7. Election of committed cluster-manager(s), with high level professional competence, widerange regional, sectoral connection network and the support of the participants.

8. Efficient common marketing activities.

9. It assumes framing an underlying environmental consciousness, which aids both guests and hosts in their perception of the environment.

10. Quick and efficient flow of information and synergic effects.

\section{SUMMARY: The role of the government in the development}

The task of the government's policy is to promote the innovation of companies and to ensure an appropriate surrounding. (Sitányi 2008) This is a big challenge especially in case of new, technology-based small enterprises. In general, the following measures in scientific and technological policy can stimulate the development of innovative groups:

- Encouragement of knowledge-exchange: e.g. starting technological forecasting programs, setting up dispute groups.

- Promote the cooperation of science and industry, building and maintaining innovation networks.

- Direct government intervention: financing R\&D projects, clusters and supporting technological transfer programmes.

- The government is a consumer and procurer: education, health, defence developments.

There are other tools for the development of innovation beyond financial sponsoring and these state measures can also be realized in the region of South-Eastern Europe with relatively low cost.

- Effectiveness of the state and the adaptation of the 'value for our money' principle. We have to increase the effectiveness of the state through implementing various measures including: the promotion of SMEs in the economic development system, and innovative tourism clusters for better market presence. .

- Improving of the business confidence through the enforcement of transparency as well as the implementation of the computerized services of the governmental and municipal sector.

- Adequate legal background, controlling, monitoring and survey of effectiveness. When we establish and develop the relevant legal background, we have to consider innovation, competitiveness and the protection of intellectual property rights. It is important that the state subsidy of project-based research and development (R\&D), clusters has to be transparent and its financing has to be efficient, controlled and regularly monitored

The results of the successful Delphi research might be the basis of the pragmatic implementation of ecotourism clusters in the National Parks and Nature Reserve Areas in Hungary. According to our research, the goal is achievable: We can develop our regions on the border of EU that is economically successful and at the same time provides a liveable environment.

\section{References:}

1. Ács J. Z. and Varga A. 2002. Geography, Endogenous Growth, and Innovation, International Regional Science Review, Vol. 25, No. 1, pp.132-148.

2. Camagni, P.R. 1992. The concept of innovative milieu and its relevance for public policies in European lagging regions. Paper, presented at the $4^{\text {th }}$ Word Congress of RSA, Palma de Mallorca

3. Dőry T. 2005. Regionális innováció-politika, Dialóg Campus Kiadó, Budapest-Pécs, pp.59.

4. Faragó L. 2004. A közösségi (területi) tervezés szerepe a gazdaságfejlesztésben. In: Pálné Kovács Ilona: Versenyképesség és igazgatás, MTA RKK, Pécs, pp.59. 
5. Fodor Á. 2006. Ökoturisztikai klaszterek a Balatontól az Adriáig. In: Pap N. (szerk.): A Balatontól az Adriáig. PTE TTK FI Kelet-Mediterrán és Balkán Tanulmányok Központja, Pécs, pp. 157-170.

6. Fritsch, M. et al. 1998. Regionale Innovationspotentiale und innovative Netzwerke. Raumforschung und Raumordnung 4, pp.243-252.

7. Fukuyama, F 1995. Trust, the Social virtues and the creation of prosperity, The Free Press, New York

8. Hawkins D. E. 2001. A Protected Areas Ecotourism Competitive Cluster Approach to Catalyse Biodiversity Conservation and Economic Growth in Bulgaria Website: www.multilingual-matters.net/jost/012/0219/jost0120219.pdf

9. Hrubi L. 2004. Megyék gazdaságfejlesztési szerepe In: Pálné Kovács Ilona: Versenyképesség és igazgatás, MTA RKK, Pécs, pp.161-177.

10. Krugman, P. 1991. Geography and Trade, Massachusetts Institute of Technology Press, Cambridge, (MA)

11. Krugman, P. 1993. On the number and location of cities, European Economic Review, Vol. 37, pp.293-298.

12. Pap N. 2003. Geographic Aspects of Regional Development Policy. Development and Finance, 3. sz. pp. 81-87.

13. Putnam, R. D. 1993. The Prosperous Community: Social Capital and Public Life, The American Prospect, 13 (Spring, pp.35-42.

14. Rechnitzer J. 1998. Területi stratégiák, Dialóg Campus, Budapest, p.348

15. Samuelson, P. A. and Nordhaus W. D. 1988. Közgazdaságtan, Közgazdasági és Jogi Könyvkiadó, Budapest, p.1353.

16. Sitányi L. 2005. Helyi stratégiakutatások az infokommunikációs társadalomban. In: Pap N. and Végh A. ed. IV. magyar politikai földrajzi konferencia, PTE TTK Földrajzi Intézet, Pécs, pp. 249-261.

17. Sitányi L. 2008. A Kárpát-Balkán térség országainak versenyképessége az innovációs készségek és környezet alapján, Reményi P. and Szebényi A. ed. V. magyar politikai földrajzi konferencia: TTK Földrajzi Intézet, Pécs, pp.445-459.

18. Szabó Á. 2006. Klaszter tagság és innováció - az Eurobarometer felmérése, http://www.pbkik.hu/index.php?id=6570\&term=

19. Stöhr, W. B. 1988. On the theory and practice of local development in Europe. IIRDiscussion, Wien, pp.37.

20. Taylor, R.E. - L.L. Judd 1994. Delphi forecasting, in: Witt, S. - L. Moutinho (eds): Tourism marketing and management handbook. (2nd ed., pp. 535-539). Hertfordshire, UK: Prentice Hall International (UK) Ltd.

21. Varga A. 2003. Johann von Thünen és az "új gazdaságföldrajz” térgazdaságtana. In.: Barancsuk J, Oroszi S. és Varga A. ed. Tanulmánykötet prof. Zinhober Ferenc emlékére, PTE, Pécs, pp.85-98.

22. Wheeler, B. - T. Hart - P. Whysall 1990. Applicatiom of the delphi technique - A reply to Green, Hunter and Moore, Tourism Management, 11(2): 121-122. 